\title{
Vanilla Cultivation in Southern Florida ${ }^{1}$
}

\section{Alan H. Chambers, Pamela Moon, Vovener de Verlands Edmond, and Elias Bassil ${ }^{2}$}

\author{
Scientific name: Vanilla planifolia \\ Common names: Vanilla orchid \\ Family: Orchidaceae \\ Origin: Mesoamerica \\ Distribution: Globally from latitudes $27^{\circ} \mathrm{N}$ to $27^{\circ} \mathrm{S}$.
}

\section{Abstract}

Vanilla extract is popular around the world as an ingredient in ice cream and various other desserts. The botanical source of vanilla extract is primarily the cured beans of Vanilla planifolia. The United States is the world's largest importer of vanilla beans, but domestic production is minimal. Southern Florida has a favorable growing environment for vanilla cultivation. This document includes information relevant to growers interested in establishing a vanillery.

\section{History}

Vanilla seed capsules (commonly called beans) have long been appreciated for their distinct aroma and flavor. The major commercial species is $V$. planifolia, with $V$. $\times$ tahitensis cultivated to a lesser extent. Madagascar leads the world in vanilla production, with Indonesia, Uganda, India, Comoros, Mexico, and other countries significantly contributing to global production. The United States is the largest importer of vanilla beans that are further processed into vanilla extract. Vanilla extract from vanilla beans is now widely used in ice cream, baked goods, chocolate, cosmetics, and many other products.
V. planifolia spread from its native range in Mesoamerica across the Caribbean islands, into Europe, and then globally starting in the late 1500s. Colder climates relied on greenhouses to maintain this tropical species. The vines were not productive outside their native range in the absence of natural pollinators. The development of manual pollination methods in 1837 and 1841 by Charles Morren and Edmund Albius, respectively, unlocked the potential of this species for commercial production outside Mesoamerica. This timely development supported expanded production in the 1850s and 1860s in response to supply constraints from Mexico. Today, clonal descendants of the original plants are grown commercially in several countries.

Vanilla has been cultivated in the United States in Puerto Rico, Hawaii, and Florida since the early 1900s. V. planifolia was introduced from Florida into Puerto Rico twice before 1909. A vanilla industry in Puerto Rico included a grower cooperative. The USDA station in Puerto Rico conducted horticultural, breeding, and bean-curing research in support of the vanilla industry. The industry in Puerto Rico grew until the 1950s, when it declined after World War II as industrialization superseded agriculture. Hawaii received vanilla as part of trade routes before 1900. Hawaii still has vanilla production but mostly favors tourism business models. Additionally, Florida has four native vanilla species (V. barbellata, V. dilloniana, V. phaeantha, and V. mexicana) with naturalized $V$. planifolia (Figure 1). Puerto Rico has seven species growing wild ( V. barbellata, V. dilloniana, V. poitaei, V. pompona, V. claviculata, V. pompona, and $V$. planifolia). The native Florida vanilla species are

1. This document is HS1348, one of a series of the Horticultural Sciences Department, UF/IFAS Extension. Original publication date November 2019. Visit the EDIS website at https://edis.ifas.ufl.edu for the currently supported version of this publication.

2. Alan Chambers, assistant professor, Horticultural Sciences Department; Pamela Moon, biological scientist III; Vovener de Verlands Edmond, graduate student; and Elias Bassil, assistant professor, Horticultural Sciences Department; UF/IFAS Tropical Research and Education Center, Homestead, FL 33031.

The Institute of Food and Agricultural Sciences (IFAS) is an Equal Opportunity Institution authorized to provide research, educational information and other services

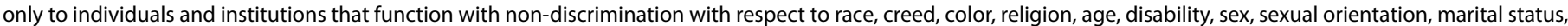

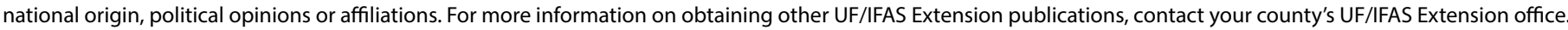
U.S. Department of Agriculture, UF/IFAS Extension Service, University of Florida, IFAS, Florida A \& M University Cooperative Extension Program, and Boards of County Commissioners Cooperating. Nick T. Place, dean for UF/IFAS Extension. 
endangered and should not be collected from natural areas without proper authorization and permitting by regulatory authorities.

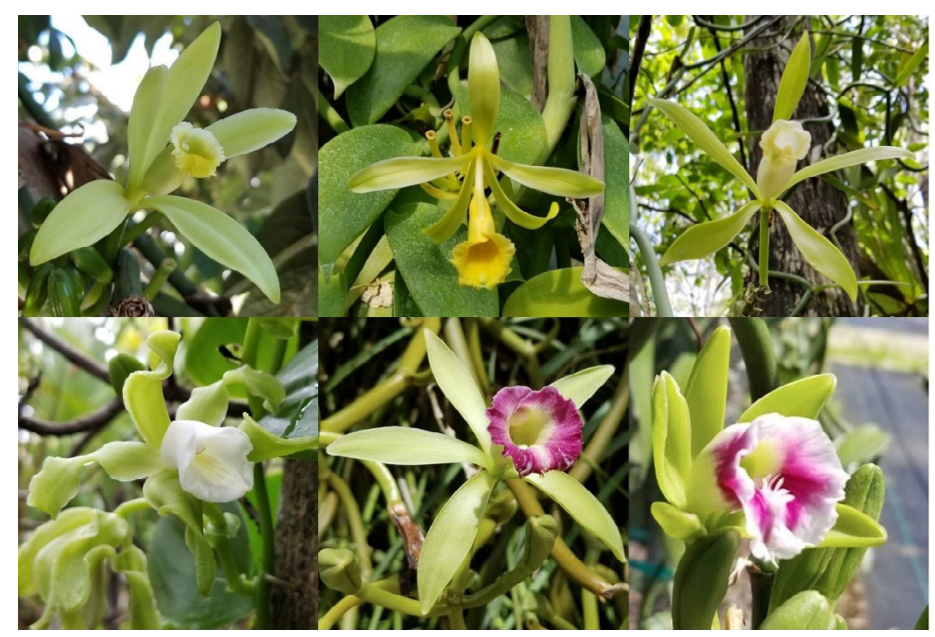

Figure 1. Flowers of $V$. planifolia (top left), $V$. pompona (top center), $V$. phaeantha (top right), $V$. mexicana (bottom left), V. dilloniana (bottom center), and $V$. barbellata (bottom right) growing in southern Florida. Credits: Alan Chambers, UF/IFAS

\section{Importance}

Vanilla extract is the second most valuable spice (after saffron) and is the world's most popular flavor. Natural vanilla extract comes predominantly from the cured beans of $V$. planifolia, which is the major commercial species, and to a lesser extent from $V . \times$ tahitensis and $V$. pompona. The aroma and flavor profiles vary for each species and from each growing environment. These differences could be useful for a variety of applications, including as food ingredients, in cosmetics, and others.

\section{Description}

\section{Plant}

$V$. planifolia is a fleshy, perennial vine with green stems.

The vines live for many years, and some species reach $60 \mathrm{~m}$ $(200 \mathrm{ft})$ in length. The stem diameter increases as the plant matures. Vanilla is semi-epiphytic, meaning it is capable of rooting in the ground and also of growing on other plants without direct soil contact.

\section{Leaves}

V. planifolia has succulent, bright green leaves. Mature leaves can be variable in size ranging from $8-25 \mathrm{~cm} \mathrm{(3-14}$ in) long and $2-8 \mathrm{~cm}(0.75-3 \mathrm{in})$ wide. They are lanceolate to oval-shaped with pointed tips and can survive about 3-4 years. Some types of $V$. planifolia have variegated leaves and are usually grown for ornamental purposes.

\section{Flowers and Fruit}

$V$. planifolia flowers are large and fragrant. Waxy creamgreen sepals form on axillary inflorescences. V. pompona flowers are diagnostically yellow compared to V. planifolia. Flowers can reach about 6 to $8 \mathrm{~cm}$ (2.5 to 3 in) in length and about 5 to $10 \mathrm{~cm}$ ( 2 to 4 in) in diameter. Two of the petals are similar in appearance to the sepals. The third petal is modified into a lip shape. This lip-shaped petal contains two pollinia (pollen masses) and the stigma, mounted on a column. A structure situated between the stigma and pollinia, called the rostellum, effectively prevents auto-pollination.

The flowers are formed in axillary bunches, with a few to many flowers per cluster, called racemes. They first appear 2-3 years after planting a new cutting. Vanilla tends to flower on larger vines when the diameter reaches 6-13 $\mathrm{mm}(0.25-0.5 \mathrm{in})$. Usually one but sometimes up to three flowers in a cluster can open at a time, usually early in the morning. Flowering usually occurs over a period of about 2 months, once a year, but each individual V. planifolia flower lasts for only one day. Flowers of some other vanilla species can remain viable longer than $V$. planifolia.

Following pollination, the ovary swells to produce a long seed capsule (bean) that can reach about $20 \mathrm{~cm}$ (8 in) in length and takes between $8-9$ months to ripen. Vanilla beans contain thousands of tiny black, round seeds. At maturity, the bean will split open along two longitudinal seams, exposing the seeds and ruining the bean for commercial purposes.

\section{Roots}

Vanilla produces two types of roots including aerial roots and terrestrial (ground) roots. Aerial roots are generally nonbranching and are formed on the stem opposite the leaves. Aerial roots primarily function to support the vine's climbing habit and are therefore very effective at adhering to supporting plants or structures. Terrestrial roots are usually found at the base of the vine, are branched, and possess root hairs that are often associated with mycorrhizae. As with other terrestrial roots, the primary role of these roots is the uptake of nutrients and water from the soil.

\section{Pollination}

Auto-pollination of $V$. planifolia flowers is rare to nonexistent in regions where native pollinators (bees and perhaps hummingbirds) do not occur. Though not native, the orchid bee Euglossa dilemma (Figure 2) has become established in southern Florida and could potentially be a pollinator 
of vanilla orchids. Otherwise, our observations in natural areas show that native vanilla species will set pods in the absence of manual pollination (Figure 3). One hypothesis is that a native orchid pollinator in southern Florida could also pollinate $V$. planifolia flowers, reducing the need for manual pollination.

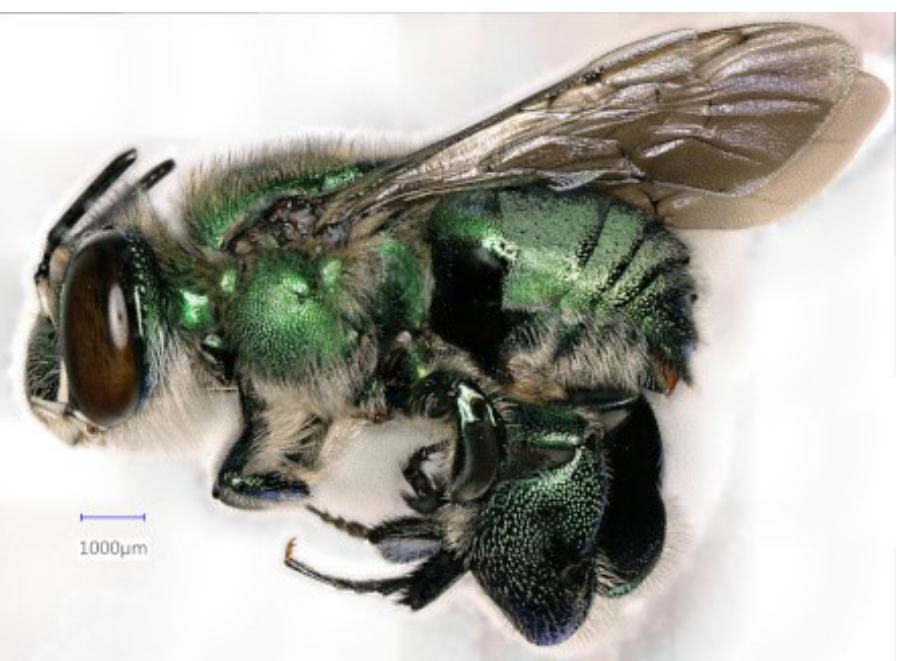

Figure 2. Euglossa dilemma lured and captured at the UF/IFAS Tropical Research and Education center. This bee could be a pollinator of vanilla orchids.

Credits: Daniel Carrillo, UF/IFAS

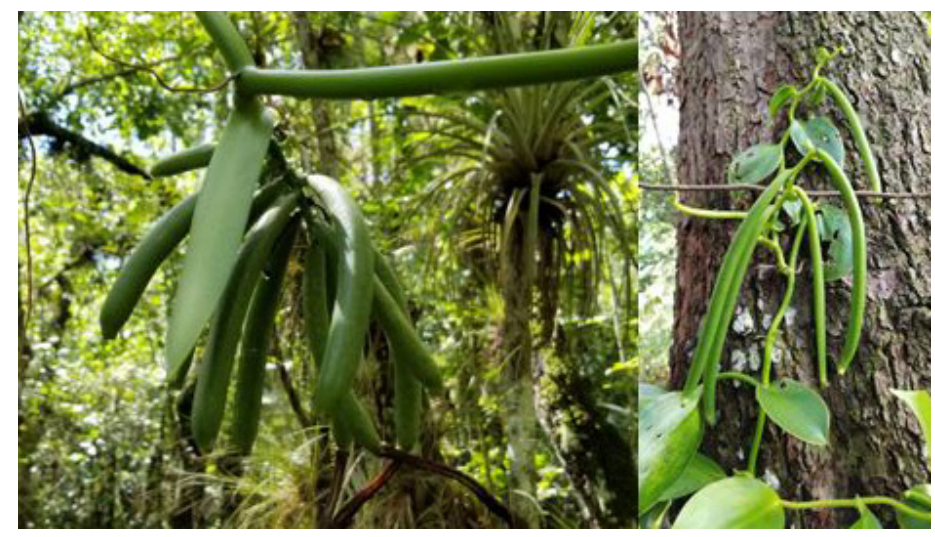

Figure 3. Bean development in the absence of manual pollination for $V$. phaeantha (left) and $V$. mexicana (right) in natural areas.

Credits: Alan Chambers, UF/IFAS

V. planifolia is generally self-compatible, meaning that pollen from one flower can be used to fertilize the same flower and lead to seed and bean development. Pollination is reportedly low $(\sim 1 \%)$ in the native Mexican range even when pollinators are present. Thus, commercial vanilla production is heavily reliant on hand pollination.

To pollinate a vanilla flower, the rostellum that separates the pollinia and the stigma needs to be bypassed. Pollinations should be attempted in the morning, usually between 6 a.m. and noon. Hand pollination can be accomplished using a toothpick or other narrow implement. Sectioned $V$. planifolia and V. pompona flowers are shown in Figure 4 to aid in describing pollination. The lower petal can be torn to expose the anthers with pollen (pollinia), rostellum, and stigmata. The rostellum is gently pushed up and away from the stigmata until the pollinia flap can be pushed towards the stigmata and make gentle contact with the stigmata. If the pollination is successful, the flower will be retained on the plant, otherwise it usually drops off in $2-3$ days. Beans will rapidly begin to swell and elongate over a few weeks if successfully pollinated.

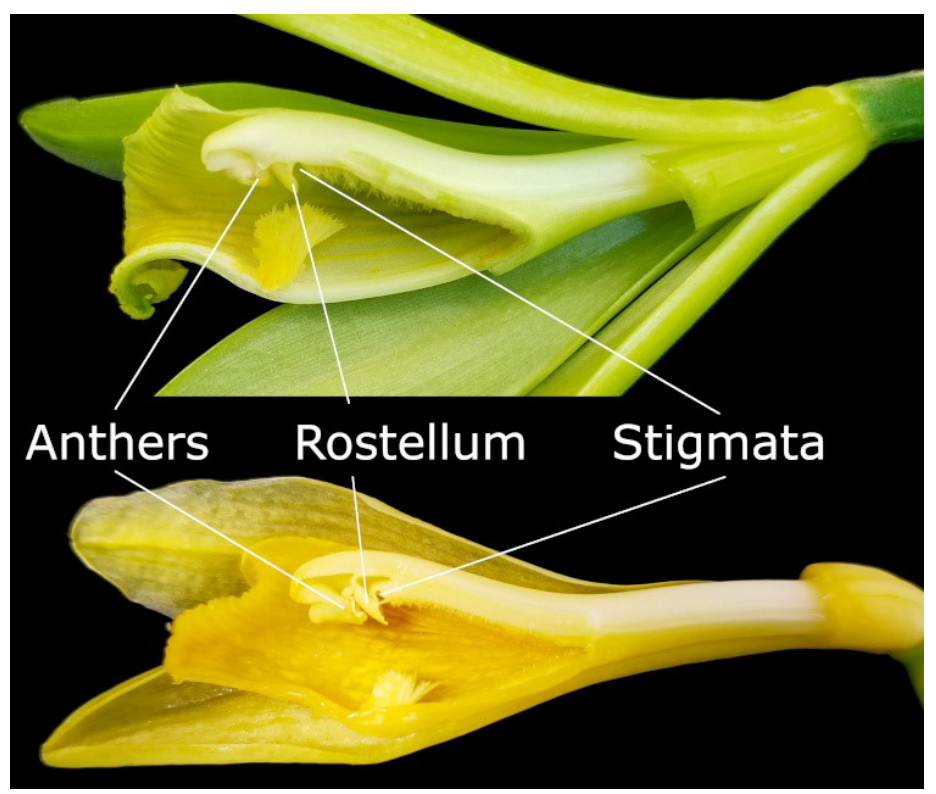

Figure 4. V. planifolia (top) and V. pompona (bottom) flowers with anthers (pollinia), rostellum, and stigmata. The stigmata are shielded directly behind the rostellum.

Credits: Alan Chambers, UF/IFAS

For commercial purposes, only the flowers on the lower side of the cluster are pollinated. The beans produced from here will grow into straight beans and command a premium price. If the plant is vigorous, a total of 8-12 flowers on $10-20$ clusters can be pollinated. Around 10 beans per cluster is desirable.

\section{Varieties}

$V$. planifolia has not generally benefited from modern plant breeding, so few named cultivars exist. Only a single cultivar, 'Handa', has been patented. This variety was developed by researchers from Réunion, and the future availability of this material is unknown. Otherwise, a few distinguishable types of $V$. planifolia have been characterized. These include 'Mansa' types originating from Mexico, which are commonly cultivated for commercial production. There are also two types of variegated $V$. planifolia generally available online and grown only for ornamental purposes. 
$V . \times$ tahitensis is the second vanilla type grown on a commercial scale. Our current understanding is that $V . \times$ tahitensis is genetically mostly $V$. planifolia with a little $V$. odorata (another vanilla species) in its ancestry. The " $x$ " denotes that this is a hybrid and not a separate species. The genetic contribution of $V$. odorata to $V$. $\times$ tahitensis seems to be minor, but has major impacts on bean splitting and aroma. The increased anise flavor notes of this type are popular in French desserts. Cuttings claiming to be $V . \times$ tahitensis can be purchased online, but our research has found that many online vendors are unknowingly selling $V$. planifolia as $V$. $\times$ tahitensis. Most international sources of verified $V . \times$ tahitensis are unwilling to share their material. Research is currently underway to verify and distribute verified $V$. $\times$ tahitensis to interested growers.

There are also risks associated with purchasing stock plants that have undesirable qualities, including sterile, lowyielding, or poor-quality types. Many of these will produce the classically beautiful vine and flowers but are not optimal for commercial cultivation. Unfortunately, the sources of these types are difficult to track because of the length of time it takes to obtain a mature, flowering vine. Research is currently underway to identify types that can consistently produce commercial-quality beans to reduce the risk to growers.

$V$. pompona is commonly grown in southern Florida by hobbyists and is also commonly mistaken for V. planifolia. $V$. pompona is vigorous but reportedly produces a lower quality extract.

\section{Environmental Conditions}

Southern Florida's hot, humid climate is suitable for vanilla cultivation. Vanilla is sensitive to cold temperatures including freezing. Therefore, a location with reduced risk of freeze events should be selected for vanilla cultivation. Optimal rainfall for vanilla has been reported around 170 to $280 \mathrm{~cm}$ per year (67 to $110 \mathrm{in} /$ year). Vanilla requires about two months of a dry season to initiate flowering. Excessively wet conditions during capsule ripening can lead to bean rot. Supplemental irrigation can be useful for establishing new cuttings and potentially for frost protection. Figure 5 shows average monthly rainfall and temperatures as recorded by the FAWN weather station at the UF/IFAS Tropical Research and Education Center.
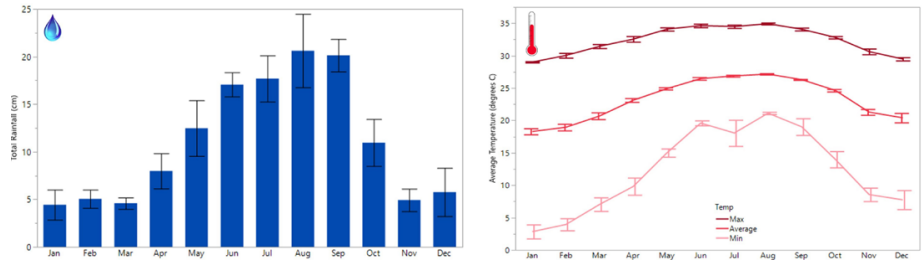

Figure 5. Average monthly rainfall and max, average, and min temperatures for Homestead, FL. Data are averages from 10 years spanning 2006 to 2016.

\section{Propagation}

Vanilla is primarily propagated by cuttings. It is important to let cut sites heal prior to planting by leaving fresh cuttings at room temperature under low light for 1-2 days. All other factors being equal, the longer the cutting, the more quickly the vine will establish and begin to flower. Cuttings that are $30 \mathrm{~cm}$ (12 in.) long will generally require 3-4 years to flower, while meter-long cuttings should flower in $2-3$ years.

Cuttings can be placed directly on top of the growth substrate (mulch from various sources) as soon as the cut sites have healed. Misting will help vines retain leaves and support the rapid development of new roots and shoots. The apical end of longer cuttings can be tied to a support post with only the distal 1-2 nodes in contact with the substrate. Leaves should be removed from nodes that are in contact with the growing substrate.

Tissue-culture V. planifolia plants are available from a few companies. Tissue-culture plants are attractive as a clean source of starting material but will take 3-4 years to mature and flower. Tissue-culture plants received in enclosed containers will need to be hardened in soilless mix under humidity domes and bright indirect light for a few weeks to months before they can survive in an environment with lower humidity and free-flowing air. Regular light misting will increase the survival of young tissue-culture plants.

Vanilla is not commonly propagated by seed due to germination challenges. The thick, highly lignified seed coat prevents timely germination, and seeds take significantly longer to grow into mature plants than cuttings. In addition, seed germination is likely reliant on associations with fungi or other microorganisms. Such constraints have supported the use of cuttings as the primary propagation method.

\section{Production Methods}

Vanilla vines require trellising to maximize production. Two major production methods are used. One uses "tutor" trees to provide both shade and a suitable structure on 
which the vines can climb. Tutor trees can be selected based on hardiness in a given location, availability, and co-cultivation considerations. This type of cultivation can be less expensive in some areas and also naturally reduces the risk of vine death by Fusarium by increasing the distance between plants. Growers in southern Florida should consider vanilla as a secondary crop on existing fruit trees. Figure 6 shows V. pompona growing on an avocado tree. Any agricultural inputs will have to be compatible with both species under the intercropping model.

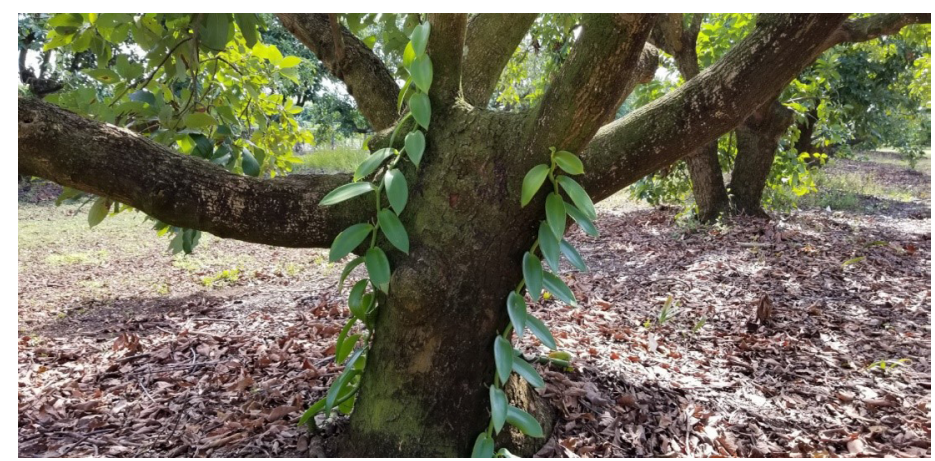

Figure 6. V. pompona growing on an avocado tree. Vines were received as $\sim 1$ meter-long cuttings. Growth is after one year without supplemental irrigation.

Credits: Alan Chambers, UF/IFAS

More intensive cultivation under shade structures can increase yields. This system requires more initial investment for infrastructure but allows for increased planting density and yield potential. Trellis support systems vary greatly but are generally made of vertical wood or concrete supports with wire running between them. Supports vary in height but are usually no more than $2 \mathrm{~m}(6 \mathrm{ft})$ tall to facilitate pollination once vines mature. The post and wire system allows for greater control over vine spacing compared to tutor trees. Vines will need to be maintained on $15-20 \mathrm{~cm}$ (6-8 in) of a mulch substrate.

\section{Spacing and Planting}

An estimated 1,000 plants per acre is often used for establishing a commercial vanillery. Spacing recommendations

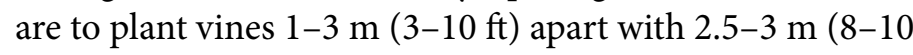
$\mathrm{ft})$ between rows.

\section{Soils}

Vanilla can be grown in a wide range of soil types but thrives in light soils with plenty of organic material. For the tutor-tree method, a slight slope may be beneficial to reduce the incidence of standing water and disease. Dry soils will require additional irrigation to maintain adequate soil moisture. Under more intensive cultivation systems, soil moisture can be regulated by managing the height of raised mulch beds.

Mulch is a popular substrate for vanilla cultivation. The particular type of mulch is not as important as its ability to provide a slow release of nutrients and retain an optimal level of moisture for roots. Some areas rely on aged coconut husks to mulch vines. Mulch will need to be reapplied every 6 to 12 months to replenish the source of nutrients and suppress weeds. Mulch can be applied directly on top of the resident soil without the need for incorporation into the soil.

\section{Pruning and Training}

Vines are trained to facilitate hand pollination and harvesting in a process called looping. Vines should be looped around supporting trellises or branches as they grow. Looping vines to the ground will stimulate terrestrial roots to form, especially if they are covered in mulch, leading to stronger vines.

Looped, healthy vines from mature plants can be tipped (apex removed) to induce flowering. Vine tips are cut about $15 \mathrm{~cm}$ ( 6 in) from the end (above the soil line) right before the dry season. These vines will be primed to flower in the coming months.

\section{Irrigation}

The natural rain cycles of Florida are favorable for vanilla production. The rainy season, along with the high summer temperatures, stimulates rapid growth. The drier season induces a rest period needed prior to flowering. As a result, established vanilla plants sometimes may not require supplemental irrigation except during extremely dry periods. Vanilla plants are tolerant of short periods of desiccation. Irrigation is more critical for commercial production than in the home landscape.

\section{Fertilization}

Vanilla cultivation relies on the slow release of nutrients from decomposing organic material. Supplemental foliar nutrition can be applied, but scientifically validated tests to justify this additional input are still lacking.

\section{Pests}

Insect pests generally do not typically cause serious damage. Snails and slugs, however, can be problematic if not controlled. We have noticed larval feeding on young plants, but we were able to manually remove the pests. 


\section{Diseases}

A major limitation to vanilla production in many regions is root and stem rot disease caused by Fusarium oxysporum. Fusarium is a ubiquitous soilborne fungus that causes rot in many species. One specialized type (Fusarium oxysporum $\mathrm{f}$. sp. radices-vanillae) causes rot in vanilla in all major producing areas by penetrating roots and spreading throughout the plant. Typical symptoms include browning and wilting, eventually leading to death of vines. The disease can be partially controlled by good horticultural practices including the avoidance of excessive waterlogging. Fungicides and biocontrol agents can have some benefit under certain conditions. Other potential fungal diseases include anthracnose and mildew.

\section{Harvesting and Traditional Curing}

Beans begin to yellow at the blossom end when fully mature. Care should be taken not to harvest beans prematurely, because this negatively impacts the quality of the resulting extract. V. planifolia beans that are left on the vine for too long have a higher propensity to split or mold, eliminating their economic value. The exception to this is $V . \times$ tahitensis, which does not display the bean-splitting trait and can be left on the vine until completely brown. Individual beans should be carefully removed from the raceme in order to avoid damaging the beans.

Vanilla beans must be cured in order to develop the characteristic vanilla aroma and flavor. Curing outcomes vary greatly by location and are heavily influenced by the growing environment, plant genetics, and maturity of the beans. Curing vanilla beans remains somewhat of an art, with many variations being used in different parts of the world. In general, curing includes a few major steps: sorting, heat-killing, sweating, gradual drying, and conditioning.

Sorting: Beans are sorted into classes including beans 16 $\mathrm{cm}$ (6 in) and longer, beans $12-16 \mathrm{~cm}$ (5-6 in), and small/ split/reject beans. Sorting beans by size is important for the heat-kill step of curing.

Heat-killing: Heat is applied at a temperature that is high enough to kill the plant cells, but not so high that the enzymes required to produce the desirable vanilla flavors would be destroyed. Water-killing at $63^{\circ} \mathrm{C}-65^{\circ} \mathrm{C}\left(145^{\circ} \mathrm{F}-\right.$ $\left.150^{\circ} \mathrm{F}\right)$ is required to arrest cell development and start the curing process. Long beans $(>16 \mathrm{~cm}, 6$ in) should be heated for $3 \mathrm{~min}$, while $12-16 \mathrm{~cm}$ (5-6 in) beans should be heated for $2.5 \mathrm{~min}$. Smaller beans can be water-killed for $2 \mathrm{~min}$ depending on the needs for the final product. After heatkilling, the beans are packed into plastic bags for sweating.
Sweating: Sweating is the process of maintaining elevated bean temperatures above $45^{\circ} \mathrm{C}\left(113^{\circ} \mathrm{F}\right)$ for $24-48$ hours after heat-killing. This can be done using insulated boxes with temperature control or by placing bottles with hot $\left(\sim 60^{\circ} \mathrm{C}, 140^{\circ} \mathrm{F}\right)$ water inside the insulated container. Beans should be dark brown after water-killing and sweating.

Gradual drying: Slowly drying the beans to a final moisture content $<25 \%$ is important for flavor development and control of microbial growth. This is traditionally accomplished over 12-15 days by removing the beans from their plastic bags, exposing them to direct sunlight for a few hours each day, and repacking into plastic bags at the end of sun treatment. This process could be mimicked using spaces that have temperature, humidity, and air-flow control. Beans are then placed on open trays to continue drying over $\sim 70$ days. Beans are sorted by quality at the end of the drying step. Any moldy beans should be discarded as they are detected.

Conditioning: Conditioning typically takes another 1-2 months. Bundled beans should be conditioned in boxes lined with paper that is impermeable to grease and oil (e.g., wax paper, parchment paper, or grease-proof paper). Beans should not be allowed to dry completely during conditioning.

\section{Making Your Own Vanilla Extract}

Only extract from two types of vanilla, $V$. planifolia and $V$. $\times$ tahitensis, can be sold as "vanilla extract" under the Code of Federal Regulations (Code of Federal Regulations Title 21 CFR169.175 and CFR169.3). The regulation dictates the solvent for vanilla extract to be not less than 35\% ethyl alcohol by volume with 13.35 ounces of vanilla beans at $25 \%$ moisture content per gallon of solvent. Smaller growers may want to consider forming cooperative ventures to improve curing and storage processes and to help ensure the uniformity and consistency of the cured vanilla beans.

\section{Basic Economics}

Many potential growers would like basic estimates for key inputs when considering the startup of a new vanillery. The available data is from other growing environments and production practices that will not necessarily reflect those of growers in southern Florida. Still, rough estimates can be useful when considering a new growing operation. The following answers to common questions are provided for estimation purposes only, and actual results will need to be empirically determined. 


\section{Answers to Common Questions}

Q: How many years until a vanilla vine will produce flowers and beans?

A: Meter-long cuttings will produce in $2-3$ years, and smaller cuttings and tissue-culture plants will take 3-4 years.

Q: How many times does a V. planifolia flower per year and when does this occur?

A: Vanilla flowers once per year usually in April-May in southern Florida.

Q: How many months does it take for a bean to ripen?

A: About 9 months after pollination.

Q: How many kilograms of green beans can one V. planifolia plant produce? How many kilograms of cured beans?

A: One healthy vanilla plant can produce $\sim 2 \mathrm{~kg}(4.4 \mathrm{lb})$ of green beans per plant. Curing is usually about $5: 1$ or $6: 1$ $\mathrm{kg}(11: 1$ or $13: 1 \mathrm{lb})$ green bean to cured bean by weight, so each plant can produce around 0.3 to $0.4 \mathrm{~kg}(0.7-0.9$ lb) cured vanilla beans.

Q: How many cured beans are in a $1 \mathrm{~kg}(2.2 \mathrm{lb})$ bundle?

A: There will be around $200-400$ cured beans in a $1 \mathrm{~kg}$ bundle.

Q: How many plants do I need per acre (hectare)?

A: Around 1,000 plants per acre (2,500 per hectare) is a good estimate, but this depends on the production method, with more plants needed for intensive, shadehouse cultivation and fewer total plants when using tutor trees.

Q: Where can I obtain V. planifolia plants?

A: Tissue-culture companies in both Florida and outside the United States (e.g., Costa Rica) can be identified by a quick internet search. Caution should be taken to ensure that these companies are selling $V$. planifolia or $V . \times$ tahitensis if you plan to sell "vanilla extract."

Q: How much labor is required during pollination?

A: A general estimate is that one person can pollinate one acre of vanilla vines. This includes monitoring the plants every day during the flowering season to pollinate freshly opened flowers.

Q: Do vanilla flowers really need to be pollinated the morning that they open?

A: Yes, vanilla flowers are only receptive for pollination for a short time. Temperatures can impact flower longevity, but pollinating before noon is usually optimal.

Q: Can I grow vanilla hybrids?

A: Certainly, but the regulatory framework for some hybrids is murky. A grower must consider their buyers and consumers when considering the cultivation of vanilla hybrids that incorporate species other than $V$. planifolia and $V$. $\times$ tahitensis. Some hybrids will be more robust and have higher disease resistance than traditional V. planifolia.

Q: How many flowers should be pollinated per raceme?

A: Usually no more than 10 beans should be allowed to develop per raceme. More could overly burden the nutritional status of the vine, leading to poor vine health the following year.

Q: How long will the vanilla vines stay in production?

A: This depends on the health of the vines, disease, and other cultural practices. You can anticipate vines staying productive for 3-5 years, but regular cycling with new, disease-free vines will aid your operation in sustainably producing beans.

\section{Additional Resources}

Bianchessi, P. 2012. Vanilla Handbook. Technical Centre for Agricultural and Rural Cooperation.

Cameron, K. 2012. Vanilla Orchids: Natural History and Cultivation. Timber Press.

Childers, N.F. 1948. Vanilla Culture in Puerto Rico. US Department of Agriculture, Washington, D.C.

Fouche, J.G., and L. Jouve. 1999. "Vanilla planifolia: History, Botany and Culture in Reunion Island." Agronomie 19: 689-703.

Havkin-Frenkel, D., and F. C. Belanger. 2018. Handbook of Vanilla Science and Technology. Wiley-Blackwell, Singapore.

Odoux, E., and M. Grisoni. 2010. Vanilla. CRC Press. 